\title{
Гострий фарингіт: роль та ефективність місцевої терапії
}

\author{
0.І. Осадчий \\ Редакція журналу «Український медичний часопис»
}

Анотація. Гострий фарингіт — одне з найпоширеніших захворювань верхніх дихальних шляхів. Основною причиною звернень хворих до сімейного лікаря є біль у горлі, лікування якого в більшості випадків може бути на 100\% ефективним за рахунок призначення місцевого лікування із застосуванням знеболювальних та протизапальних засобів. Саме вони забезпечують швидке втамування болю, зменшення локального запально-набрякового стану слизової оболонки без ризику розвитку бактеріальної резистентності. У запропонованій статті представлені відповіді на запитання, як і коли доцільно проводити таке лікування.

Ключові слова: гострі респіраторні захворювання, біль у горлі, антибіотикорезистентність, флурбіпрофен, Стрепсілс ${ }^{\circledR}$ Інтенсив.

\section{Актуальність проблеми}

Гострі респіраторні захворювання (ГРЗ) - найбільш поширена інфекційна патологія дихальних шляхів у людей, яка становить певну проблему як у соціальному, так і в медичному плані. ГРЗ відрізняються сезонним підвищенням - переважно у весняно-осінній період, мають вірусно-бактеріальну етіологію, спільні епідеміологічні ознаки поширення та патогенез із розвитком локального ураження верхніх дихальних шляхів різного ступеня вираженості та клінічних ознак респіраторного синдрому на тлі ларингіту, тонзиліту, фарингіту чи бронхіту.

Етіологічний чинник захворювання досить різноманітний. Перш за все це віруси (їх налічують понад 300 серед збудників) та бактерії: легіонели, менінгококи, стрептококи, стафілококи, рикетсії, мікоплазми, хламідії та спірохети. Таке розмаїття збудників, що спричиняє запалення верхніх дихальних шляхів, зазвичай перешкоджає своєчасній їх ідентифікації, що неминуче впливає на вибір лікувальної тактики, особливо у разі бактеріальної етіології захворювання та необхідності призначення антибактеріальної терапії. Однак варто зауважити, що лише у 15-30\% хворих збудник має бактеріальне походження.

Серед особливостей перебігу ГРЗ - практично однакова клінічна картина для багатьох захворювань, що також перешкоджає проведенню диференційної діагностики. Водночас такий симптом, як біль у горлі, $є$ доволі поширеною скаргою у багатьох хворих. Саме біль у горлі $\epsilon$ однією з найчастіших причин звернення за медичною допомогою до сімейного лікаря або педіатра. Необхідно брати до уваги, що ГР3 становлять 70\% від усіх звернень за допомогою на первинній ланці.

I ще: біль у горлі - найбільш поширена причина призначення антибіотиків у світі, попри те що переважна більшість ГРЗ має вірусну етіологію - майже у 85-90\% випадків! У більшості паці$\epsilon$ нтів хвороба має схильність до самообмеження та не потребує антибактеріального лікування [1-3].

Ситуація, з огляду на стрімкий і неконтрольований розвиток антибіотикорезистентності у світі, доволі серйозна. Водночас необхідність своєчасного та виправданого призначення антибіотиків, аби уникнути розвитку фатальних ускладнень ГРЗ у хворого, на сьогодні $\epsilon$ проблемою невирішеною і доволі суперечливою в плані однозначних рекомендацій в експертному середовищі. Необхідно також брати до уваги, що серед тих, хто має бактеріальний чинник розвитку гострого фарингіту — переважно діти, збудником $\epsilon \beta$-гемолітичний стрептокок групи A (Streptococcus pyogenes), який часто асоціюється з розвитком ревматичної лихоманки та ймовірністю ускладнень із розвитком ревматичної хвороби серця чи гострого гломерулонефриту [4-8]. На щастя, частота такого ускладнення становить не більше ніж 1 на 100200 випадків гострої ревматичної лихоманки, правда, цей показник характерний лише для країн із достатнім рівнем економіч- ного розвитку та сучасним рівнем медичного обслуговування населення. Таким чином, маємо ситуацію, де, аби уникнути ймовірного розвитку ускладнень у менше ніж 15\% пацієнтів, більшу їх частину наражаємо на небезпеку призначення недієвої i водночас небезпечної антибактеріальної терапії, що шкідливо для хворого і головне - сприяє підвищенню антибактеріальної резистентності хвороботворних бактерій у глобальному масштабі. У більшості випадків ситуації може зарадити призначенням місцевого лікування, спрямованого на зменшення вираженості болю та локального запально-набрякового стану слизової оболонки верхніх дихальних шляхів.

Таким чином, метою цього огляду стала низка питань, на які щодня шукає відповідь лікар первинної ланки, стикаючись із хворими на ГРЗ, а саме:

1. Коли і як призначати антибактеріальні препарати хворим на ГРЗ з огляду на ризик розвитку антибіотикорезистентності в Україні і світі?

2. Який алгоритм призначення антибіотиків хворим на ГРЗ та їх раціональне застосування?

3. Яка роль місцевого лікування, зокрема ефективність та безпека нестероїдних протизапальних препаратів (НПЗП) місцевої дії?

\section{ГР3: раціональне застосування}

\section{антибіотиків та зниження ризику}

\section{розвитку антибіотикорезистентності}

Сучасна лікувальна практика без застосування антибактеріальних засобів практично не уявляється. Ясна річ, що в цьому вбачається позитив. За час винайдення та широкого застосування антибіотиків людство забуло про трагічність таких захворювань, як туберкульоз, пневмонія, шлунково-кишкові інфекції та венеричні захворювання. Усі вони, здається, залишилися в далекому минулому. Однак невиправдано широке та нераціональне застосування антибактеріальних препаратів призвело до загрозливої ситуації - формування резистентності мікроорганізмів до більшості з відомих протимікробних засобів. На сьогодні оберти формування антибіотикорезистентності набули масштабу «пандемії» з ознаками соціально-економічної катастрофи. Резистентність до відомих і ще досить ефективних протимікробних засобів набула загрозливих масштабів. Попри те що процес $\epsilon$ природним, внаслідок нераціонального застосування антибіотиків відбувається селекція резистентних штамів, які можуть легко набувати нові механізми резистентності і поширюватися серед госпіталізованих хворих, а також поза межі стаціонару, знижуючи ефективність лікування та збільшуючи госпітальні затрати на процес реабілітації хворих. Зусилля, спрямовані на виділення нових антибактеріальних препаратів, не увінчалися бодай мінімальними обнадійливими 
результатами, а отримані препарати лише були модифікацією вже відомих. Майже всі нові антибіотики, які були випущені в обіг в останні десятиліття, $\epsilon$ різновидами класів антибіотиків, відкритих ще до 1980-х років. Згідно з даними нової Глобальної системи нагляду за резистентністю до протимікробних препаратів (Global antimicrobial resistance surveillance system - GLASS) Всесвітньої організації охорони здоров'я близько 500 тис. осіб з підозрою на бактеріальну інфекцію у 22 країнах зіштовхнулися зі стійкістю до антибіотиків виявлених збудників. Раціональне та пацієнтоорієнтоване лікування з дотриманням сурових вимог до призначення антимікробних препаратів може стати на заваді подальшому розвитку антибіотикорезистентності у світі і в України зокрема $[9,10]$.

В Україні відмічають суттєво велику частку госпіталізацій з приводу захворювань верхніх та нижніх дихальних шляхів, а також туберкульозу - близько 15,2\% у структурі госпіталізованих, що значно вище, ніж у сусідніх країнах. У структурі первинної дитячої захворюваності хвороби дихальних шляхів також займають головне місце. Усі зазначені стани традиційно мають лікувальну тактику, де антибіотики займають провідну позицію. Призначення антибіотиків за нозологічними формами та їх частка у структурі лікування за нозологіями ГРЗ наведена на малюнку.

Малюнок Частка призначення антибіотиків за нозологіями за спеціальностями лікарів [11]

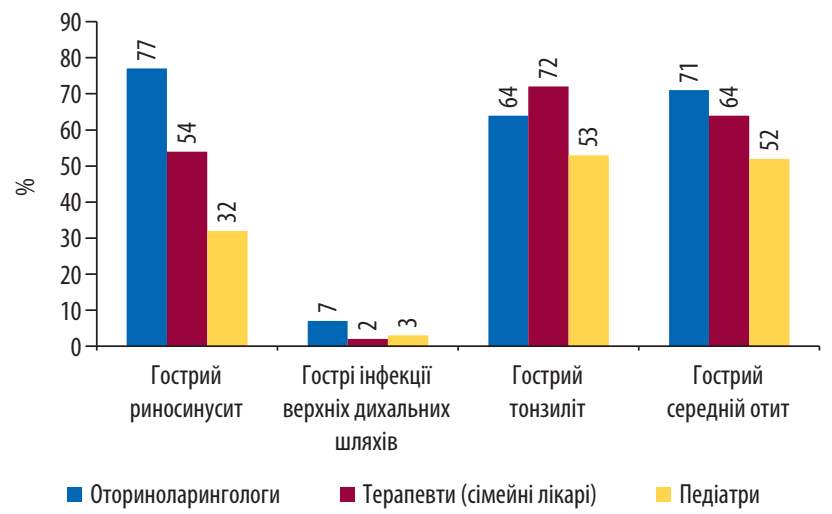

ГРЗ становлять близько 70-75\% усіх звернень до дільничного лікаря, а біль у горлі - основна причина призначення антибактеріальних препаратів 85\% пацієнтів, що звернулися на первинну ланку медичної допомоги. Головною причиною зазвичай $\epsilon$ гострий фарингіт - одне з найчастіших захворювань носоглотки. Попри те що бактеріальним збудником доволі часто може бути $\beta$-гемолітичний стрептокок групи A, його причетність до розвитку гострого фарингіту вдається встановити лише у $30 \%$ дітей та $10 \%$ дорослих. Тобто лише у $10 \%$ випадків призначення антибактеріальної терапії є кроком цілком виправданим, оскільки знижує ризик розвитку ревматичної лихоманки, запобігає формуванню інтоксикаційного синдрому, скорочує тривалість перебігу захворювання та знижує ризик розвитку ревматичної хвороби серця.

Однак, попри користь застосування антибактеріальної терапії для попередження розвитку небезпечних ускладнень у лікуванні гострого фарингіту, цей крок не завжди виправданий. Застосування антибіотиків рекомендується проводити особливо виважено і лише у випадку доведеної необхідності. Незважаючи на таку пересторогу, антибіотики $\epsilon$ у переліку першочергового призначення у половині візитів хворих до сімейного лікаря. Однак у більшості випадків призначення антибіотиків $\epsilon$ «упереджувальною, захисною» тактикою сімейного лікаря. Така позиція не лише сприяє необгрунтованому призначенню антибактеріальної терапії, а й $є$ рушійним джерелом підвищеного ризику розвитку антибіотикорезистентності $[12,13]$.

Аби спростити та полегшити призначення антибактеріальної терапії хворим на гострий фарингіт, використовують рекомендації, які:

- враховують лише клінічні критерії;
- враховують клінічні критерії з оцінкою за шкалою Р.М. Сентора (R.M. Centor, 1981) у модифікації Мака - Айзека (W.J. Mclsaac, 1998);

- побудовані лише на оцінці даних лабораторних досліджень.

Європейські та Північноамериканські рекомендації базуються на критеріях R.M. Centor (1981) або W.J. Mclsaac (1998) та обов'язковому виконанні швидкого тесту на визначення антигену $\beta$-гемолітичного стрептококу групи А. У разі виникнення сумніву або ситуації, яка наводить на думку щодо необхідності призначення антибактеріальної терапії, варто виконати додаткові обстеження, які додадуть впевненості такого кроку, а саме:

- бактеріологічнедослідження мазківіз горлана $\beta$-гемолітичний стрептокок групи A;

- бактеріологічне дослідження мазків із горла на виявлення гонококу та хламідій;

- дослідження на наявність гетерофільних антитіл у сироватці крові до вірусу Епштейна - Барр;

- тест полімеразної ланцюгової реакції для виявлення $\beta$-гемолітичного стрептококу групи A.

У табл. 1 та 2 наведено шкали R.M. Centor (1981) та W.J. Mclsaac (1998), які варто використовувати лікарю у своїй діяльності для спрощення прийняття рішення про доцільність призначення антибактеріальної терапії (табл. 3) [14], а також деякі поради щодо оцінки отриманих результатів застосування цих шкал. Варто звернути також увагу на:

- повідомлення про ознаки лихоманки, отримані при спілкуванні з хворим, має більше значення і $\epsilon$ більш чутливим критерієм, аніж вимірювання температури тіла під час огляду;

- гнійний наліт на мигдаликах та лімфаденопатія переднього шийного трикутника - ознаки, що підвищують імовірність бактеріальної інфекції;

- при однобічному набряку шиї, лихоманці з ознобом, відсутності полегшення впродовж 5-7 днів лікування - виключити синдром Лем'єра [15] (!);

- відсутність ефекту від лікування впродовж 1-2 тиж - виключити гострий лейкоз (!);

- ознаки нежитю та наявність кашлю свідчать на користь вірусної етіології фарингіту;

- якщо за шкалою R.M. Centor пацієнт має 0 балів або 1 бал за модифікованою шкалою W.J. Mclsaac - призначати антибактеріальну терапію недоцільно (не потрібно); швидкий тест на виявлення $\beta$-гемолітичного стрептококу групи А не виконують!

Чого необхідно досягти та чого варто остерігатися - питання, які постають і варті уваги, оскільки частота гострого бактеріального фарингіту $\epsilon$ невисокою. Однак своїми діями лікар має сприяти досягненню:

- попередження розвитку гострої ревматичної лихоманки;

- попередження розвитку гнійно-некротичних ускладнень;

- зменшення вираженості клінічної симптоматики й ознак запального процесу;

- зниження ймовірності інфікування оточуючих $\beta$-гемолітичним стрептококом групи А;

- мінімізації потенційних побічних ефектів невідповідної антимікробної терапії.

\section{Гострий фарингіт: роль неспецифічної терапії}

Надалі розглянемо проблему лікування гострого фарингіту із застосуванням неспецифічної терапії. Як зазначено вище, 8590\% випадків гострого фарингіту етіологічно пов'язано з вірусним чинником. Саме неспецифічна терапія довела свою дієвість і безпеку в цій ситуації. Вона має високу ефективність, не впливає на процес формування антибіотикорезистентності, швидко полегшує загальний стан хворого, позбавляє болю в горлі, викликаючи мінімальну кількість побічних ефектів. Переважно це пацієнти, які мають оцінку за шкалою R.M. Centor/W.J. Mclsaac 0-0,5 бала і мінімальний ризик бактеріальної контамінації. Засоби, які 
Таблиця 1 Шкала R.M. Centor (1981)

\begin{tabular}{|c|c|c|}
\hline \multicolumn{2}{|r|}{ Оціночний критерій } & $\begin{array}{l}\text { Оцінка } \\
\text { (бали) }\end{array}$ \\
\hline \multicolumn{2}{|c|}{ Температура тіла $>38^{\circ} \mathrm{C}$} & 1 \\
\hline \multicolumn{2}{|c|}{ Відсутність кашлю } & 1 \\
\hline \multicolumn{2}{|c|}{ Збільшені та болючі шийні лімфовузли } & 1 \\
\hline \multicolumn{2}{|c|}{ Набухлі глоткові мигдалики з ексудацією } & 1 \\
\hline \multicolumn{3}{|c|}{ Інтерпретація/оцінка отриманих результатів обстеження } \\
\hline Бали & \multicolumn{2}{|c|}{$\begin{array}{c}\text { Вірогідність виділення культури } \beta \text {-гемолітичного стрептококу групи А } \\
\text { при бактеріологічному дослідженні, \% }\end{array}$} \\
\hline 0 & \multicolumn{2}{|l|}{2,5} \\
\hline 1 & \multicolumn{2}{|l|}{$6-6,9$} \\
\hline 2 & \multicolumn{2}{|l|}{$14,1-16,6$} \\
\hline 3 & \multicolumn{2}{|l|}{$30,1-34,1$} \\
\hline 4 & \multicolumn{2}{|l|}{55,7} \\
\hline
\end{tabular}

Таблиця 2 ШкалаW.J. Mclsaac (1998) (модифікована шкала R.M. Centor, 1981)

\begin{tabular}{lc}
\hline \multicolumn{1}{c}{ Оціночний критерій } & Оцінка (бали) \\
\hline Температура тіла $>38^{\circ} \mathrm{C}$ & 1 \\
\hline Відсутність кашлю & 1 \\
\hline 3більшені та болючі шийні лімфовузли & 1 \\
\hline Набухлі глоткові мигдалики з ексудацією & 1 \\
\hline Вік, роки & 1 \\
\hline $3-14$ & 0 \\
\hline $15-44$ & 1 \\
\hline$\geq 45$ &
\end{tabular}

Інтерпретація/оцінка отриманих результатів обстеження

\begin{tabular}{|c|c|c|}
\hline Бали & $\begin{array}{l}\text { Вірогідність виділення } \\
\text { культури } \beta \text {-гемолітичного } \\
\text { стрептококу групи А } \\
\text { при бактеріологічному } \\
\text { дослідженні, \% }\end{array}$ & Тактика \\
\hline 0 & $1-2$ & $\begin{array}{l}\text { Обстеження та подальше лікування } \\
\text { не потрібне (антибіотик не призначають!) }\end{array}$ \\
\hline 1 & $5-10$ & \multirow{2}{*}{$\begin{array}{l}\text { Мазок-відбиток. При позитивному } \\
\text { результаті — призначити антибіотики }\end{array}$} \\
\hline 2 & $11-17$ & \\
\hline 3 & 28-35 & \multirow{2}{*}{$\begin{array}{l}\text { Емпіричне лікування/антибіотики (висока } \\
\text { лихоманка, погане загальне самопочуття, } \\
\text { короткий термін хвороби), водночас } \\
\text { бактеріологічне обстеження }\end{array}$} \\
\hline 4 & $51-53$ & \\
\hline
\end{tabular}

рекомендовано для застосування, - нестероїдні протизапальні препарати (НПЗП) та парацетамол [16-20].

Ще раз зазначимо, що біль у горлі $\epsilon$ провідним клінічним симптомом у хворих на ГРЗ. Він надзвичайно виснажливий, позбавляє здатності нормально дихати та розмовляти, а у дітей викликає підвищену дратівливість, порушення сну та поведінкових реакцій. Саме біль у горлі $\epsilon$ основною причиною звернень хворих за допомогою, а також надмірного і невиправданого застосування антибіотиків - при тому, що їх користь для усунення больового синдрому виявляється мінімальною і потребує повторного відвідування лікаря у 84,5\% випадків. Так, в одному з досліджень показано, що лише кожний 10-й пацієнт, який звертався за допомогою з приводу болю в горлі, отримав користь від антибактеріальної терапії, а її призначення здебільшого ініціювалося лікарем надмірно й упереджено. Таким чином, слід зробити висновок, що більшість пацієнтів, які звертаються за допомогою, перш за все очікують отримати лікування, яке зумовить зменшення вираженості больового синдрому.

Доведено, що біль у горлі викликаний продукцією брадикінінів та простагландинів - медіаторів гострого запалення, у відповідь на вірусну інфекційну інвазію [21]. Саме з точки зору недоцільності призначення антибактеріальних препаратів як малоефективних і таких, що радше можуть завдати шкоди, аніж користі, і не викликають полегшення болю (головного чинника
Таблиця 3 Поради лікаря при певних стратегіях антибіотикотерапії [14]

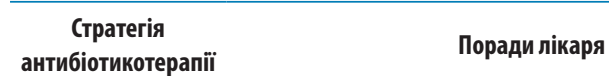

Непризначення Запевнити, що антибіотики не потрібні на цей час, оскільки вони можуть незначною мірою вплинути на перебіг хвороби, але можуть спричинити побічні реакції (наприклад діарею, блювання, висип тощо). Призначити повторний клінічний огляд у разі, якщо стан пацієнта погіршується або відсутня динаміка

\begin{tabular}{ll}
\hline Відкладене & Запевнити, що антибіотики не потрібні на цей час, оскільки вони \\
призначення & можуть незначною мірою вплинути на перебіг хвороби, але \\
& можуть спричинити побічні реакції (наприклад діарею, блювання \\
& висип тощо). Надати поради щодо того, коли розпочати прийом \\
& антибіотиків (симптоми не зникають протягом 2 діб або стан \\
& погіршується). Рецепт видати одразу. Призначити повторний \\
& клінічний огляд в разі, якщо стан пацієнта погіршується чи \\
& відсутня позитивна динаміка через 2 доби від початку прийому \\
& антибіотиків
\end{tabular}

Негайне призначення Запропонувати негайно розпочати прийом антибіотиків або подальше обстеження та лікування у стаціонарі пацієнтам: у тяжкому стані; із симптомами та ознаками серйозної хвороби та/чи ускладнення (пневмонії, мастоїдиту, перитонзилярного абсцесу, перитонзилярної флегмони, внутрішньоочних або внутрішньочерепних ускладнень); які належать до групи високого ризику розвитку тяжких ускладнень у зв'язку із вже існуючими супутніми хворобами (хворобами серця, легень, нирок, печінки, хворобами нервово-м'язового апарату, імуносупресією, муковісцид0зом); дітям перших місяців життя, які народилися недоношеними; віком понад 65 років із гострим кашлем i $\geq 23$ наступних критеріїв або старше 80 років $\mathrm{i} \geq 1$ з наступних критеріїв: госпіталізація у попередньому році, цукровий діабет 1-го або 2-го типу, гостра серцева недостатність в анамнезі, поточне застосування пероральних глюкокортикоїдів; дітям віком до 2 років із двобічним середнім отитом; дітям з отореєю, що виникла внаслідок гострого середнього отиту; пацієнтам із гострим болем у горлі/гострим тонзилітом, коли $€ \geq 3$ критеріїв R.M. Centor.

звернення за допомогою), їх не можна застосовувати як лікувальний засіб першої лінії! Антибіотики необхідно призначати виключно у разі підтвердженого бактеріального інфікування або ознак тяжкого ускладнення. Препаратами 1-го призначення мають стати знеболювальні і протизапальні засоби. Одним із таких засобів $є$ флурбіпрофен - НПЗП, знеболювальну дію якого доведено у хворих із гострим фарингітом у низці досліджень [22-26]. Попередньо випробовували препарат у формі льодяників, які містили 8,75 мг флурбіпрофену. Препарат чинив потужну протизапальну та знеболювальну дію шляхом пригнічення ферменту циклооксигенази (ЦОГ) та синтезу простагландинів. Механізм знеболювальної дії, швидкість та тривалість настання ефекту і безпека препарату добре вивчені. Наступним кроком стало створення препарату у формі спрею. Цей інноваційний метод забезпечує швидке та тривале зменшення вираженості симптомів, значно спрощує застосування та безпеку тривалого застосування. Результати застосування флурбіпрофену у формі спрею у добре спланованому плацебо-контрольованому дослідженні довели його високу знеболювальну ефективність та досить тривалу дію - до 6 годин. Порівняно з плацебо спрей флурбіпрофену забезпечив набагато більше зменшення вираженості болю в горлі, набрякового стану за рахунок глибокого проникнення у слизову оболонку, болючості при ковтанні. Його застосування сприяло зниженню інтенсивності болю та швидкому зменшенню відчуття болю в горлі вже наприкінці 1-го дня, через 24 год, а також наприкінці 2-го і 3-го днів $(p<0,05)$ для всіх досліджуваних. У висновку дослідження зазначено, що застосування флурбіпрофену у формі спрею в дозі 8,75 мг (максимум 5 разів на добу протягом 3 днів) забезпечує ефективне зменшення вираженості всіх симптомів, перш за все болю, у хворих на гострий вірусний фарингіт [27-32].

На фармацевтичному ринку України представлений препарат флурбіпрофену у формі спрею та льодяників із вмістом діючої речовини 8,75 мг із торговою назвою Стрепсілс ${ }^{\circledR}$ Інтенсив. Препарат 
забезпечує потужну протизапальну та знеболювальну дію за рахунок глибокого проникнення в товщу слизової оболонки ротоглотки та пригнічення синтезу простагландинів та цитокінів, знижує активність ЦОГ-1 та ЦОГ-2 і, відповідно, набряковий синдром, а головне - відчуття болю.

\section{На завершення необхідно підкреслити:}

1. Для полегшення прийняття рішення варто ширше використовувати шкали R.M. Centor або W.J. Mclsaac та обов'язково виконувати швидкий тест на визначення антигену $\beta$-гемолітичного стрептококу групи А.

2. Лікування болю в горлі варто розпочинати з призначення препаратів із знеболювальною дією.

3. У якості препарату вибору можна рекомендувати Стрепсілс ${ }^{\circledast}$ Інтенсив у формі спрею, який містить 8,75 мг НПЗП флурбіпрофену, що має здатність пригнічувати ЦОГ-1 та ЦОГ-2, проникати в глибокі шари слизової оболонки в зоні запалення та швидко полегшувати біль у горлі. Препарат діє незалежно від природи інфекції та здатен підсилювати дію антибіотиків у разі необхідності їх застосування.

\section{Список використаної літератури}

1. Leshem S., Tabenkin H., Dan E. et al. (1999) Knowledge and practice of primary care physicians relating to the treatm. Harefuah., 136(6): 438-441.

2. Centor R.M., Samlowski R. (2011) Avoiding Sore Throat Morbidity and Mortality: When Is It Not «Just a Sore Throat? Am. Fam. Physician, 83(1):26-28.

3. Sorethroat (acute): antimicrobial prescribing. NICEguideline [NG84] Published: 26 January 2018.

4. Weil-Olivier C. (2004) Rheumatic fever. Orphanet encyclopedia.

5. Seckeler M.D., Hoke T.R. (2011). The worldwide epidemiology of acute rheumatic fever and rheumatic heart disease. Clin. Epidemiol., 3: 67-84.

6. Bisno A.L., Gerber M.A., Gwaltney J.M.Jr. et al. (2002) Practice guidelines for the diagnosis and management of group A streptococcal pharyngitis. Infectious Diseases Society of America. Clin. Infect. Dis., 35(2): 113-125.

7. Bisno A.L., Gerber M.A., Gwaltney J.M.Jr. et al. (1997) Diagnosis and management of group A streptococcal pharyngitis: a practice guideline. Infectious Diseases Society of America. Clin. Infect. Dis., 25: 574-583.

8. Dajani A., Taubert K., Ferrieri P. et al. (1995) Treatment of acute streptococcal pharyngitis and prevention of rheumatic fever: a statement for health professionals. Committee on Rheumatic Fever, Endocarditis, and Kawasaki Disease of the Council on Cardiovascular Disease in the Young, the American Heart Association. Pediatrics, 96(4 pt. 1): 758-764.

9. www.who.int/ru/news/item/29-01-2018-high-levels-of-antibiotic-resistance-foundworldwide-new-data-shows.

10. Rimoin A.W., Hamza H.S., Vince A. et al. (2005) Evaluation of the WHO clinical decision rule for streptococcal pharyngitis. Arch. Dis. Child., 90(10): 1066-1070.

11. Попович В.І. (2020) Раціональне лікування небактеріальних та бактеріальних інфекцій верхніх дихальних шляхів у рамках проблеми стримування зростання бактеріальної резистентності. Укр. мед. часопис, 1(1)(135): https://www.umj.com.ua/article/169299.

12. van Driel M.L., De Sutter A., Deveugele M. et al. (2006) Are Sore Throat Patients Who Hope for Antibiotics Actually Asking for Pain Relief? Ann. Fam. Med., 4(6): 494-499.
13. Altiner A., Brockmann S., Sielk M. et al. (2007) Reducing antibiotic prescriptions for acute cough by motivating GPs to change their attitudes to communication and empowering patients: a cluster-randomized intervention study. J. Antimicrob. Chemother., 60(3): 638-644.

14. Устінов 0.В. (2014) Алгоритм діїлікаря при наданні медичноїдопомоги хворим на гострі респіраторні інфекції. Укр. мед. часопис, 6(104): https://www.umj.com.ua/article/83046

15. Lemierre A. (1936) On certain septicaemias due to anaerobic organisms. Lancet, 227(5874): 701-703.

16. Kenealy T., Arroll B. (2013) Antibiotics for the common cold and acute purulent rhinitis. Cochrane Database Syst. Rev., 2013(6): CD000247. doi: 10.1002/14651858.CD000247.pub3.

17. Spinks A., Glasziou P.P., Del Mar C.B. (2013) Antibiotics for sore throat. Cochrane Database Syst. Rev., 11: CD000023.

18. van der Velden A., Bell J., Sessa A. et al. (2013) Sore throat: effective communication delivers improved diagnosis, enhanced self-care and more rational use of antibiotics. Int. J. Clin. Pract., 67(S180): 10-16.

19. Cooper R.J., Hoffman J.R., Bartlett J.G. et al. (2001) For the American Academy of Family Physicians, American College of Physicians, American Society of Internal Medicine, Centers for Disease Control and Prevention. Principles of appropriate antibiotic use for acute pharyngitis in adults: background. Ann. Intern. Med., 134(6): 509-517.

20. Advisory Group on Antibiotic Stewardship Programme in Primary Care; Chan A.M.W., Au W.W.Y., Chao D.V.K. et al. (2019) Antibiotic management of acute pharyngitis in primary care. Hong Kong Med. J., 25(1): 58-63. doi: 10.12809/hkmj187544.

21. Rees G.L., Eccles R. (1994) Sore throat following nasal and oropharyngeal bradykinin challenge. Acta Otolaryngol., 114: 311-314.

22. Schachtel B., Aspley S., Shephard A. et al. (2014) Onset of action of a lozenge containing flurbiprofen $8.75 \mathrm{mg}$ : a randomized, double-blind, placebo-controlled trial with a new method for measuring onset of analgesic activity. Pain, 155: 422-428.

23. Sefia E., Mann A., Lambkin R. et al. (2007) Flurbiprofen lozenges rapidly reduce levels of the inflammatory mediator prostaglandin $\mathrm{E}$ in human respiratory cells in vitro. Abstract presented at the Annual Scientific Meeting of the British Pain Society, 24-27 April, Glasgow, Scotland.

24. Schachtel B., Aspley S., Shephard A. et al. (2014) Utility of the sore throat pain model in a multiple-dose assessment of the acute analgesic flurbiprofen: a randomized controlled study. Trials, 15: 263.

25. de Looze F., Russo M., Bloch M. et al. (2016) Efficacy of flurbiprofen $8.75 \mathrm{mg}$ spray in patients with sore throat due to an upper respiratory tract infection: A randomised controlled trial. Eur. J. Gen. Pract., 22: 111-118.

26. Russo M., Bloch M., de Looze F. et al. (2013) Flurbiprofen microgranules for relief of sore throat: a randomised, double-blind trial. Br. J. Gen. Pract., 63: e149-e155.

27. Snow V., Mottur-Pilson C., Cooper R. et al. (2001) Principles and appropriate use for acute pharyngitis in adults. Ann. Intern. Med., 134: 506-508.

28. Старучинский Л.С., Белоусов Ю.Б., Козлов С.Н. (ред.) (2002) Практическое руководство по антиинфекционной терапии. Боргес, Москва, 379 с.

29. Coutinho G., Duerden M., Sessa A. (2021) Worldwide comparison of treatment guidelines for sore throat. Int. J. Clin. Pract., 75: e13879. doi.org/10.1111/ijpp.13879.

30. ESCMID Sore Throat Guideline Group, Pelucchi C., Grigoryan L. et al. (2012) Guideline for the management of acute sore throat. Clin. Microbiol. Infect., 18: 1-28.

31. van Driel M.L., De Sutter A., Deveugele M. (2006) Are Sore Throat Patients Who Hope for Antibiotics Actually Asking for Pain Relief? Ann. Fam. Med., 4(6): 494-499.

32. Coutinho G., Duerden M., Sessa A. et al. (2021) Worldwide comparison of treatment guidelines for sore throat. Int. J. Clin. Pract., 75: e13879. 


\section{Strepsils $\mathbb{S}$}

\section{СТРЕПСІЛС ${ }^{\circledR}$ |НТЕНСИВ - \\ ЕФЕКТИВНЕ СИМПТОМАТИЧНЕ ЛІКУВАННЯ БОЛЮ ВГОРЛІ}

\section{до 10 ваших пацієнтів з симптомом болю в горлі}

\section{АНТИБІОТИКИ НЕ ЗАДОВОЛЬНЯЮТЬ ПОТРЕБУ ПАЦІЄНТІВ У ШВИДКОМУ ПОЛЕГШЕННІ БОЛЮ В ГОРЛІ2 ТА МОЖУТЬ СПРИЧИНЯТИ РОЗВИТОК АНТИБІОТИКОРЕЗИСТЕНТОСТІ ${ }^{3,4}$}

На відмінну від антибіотиків Стрепсілс ${ }^{\oplus}$ Інтенсив ефективно та швидко полегшує біль у горлі незалежно від причини - вірусна чи бактеріальна інфекція

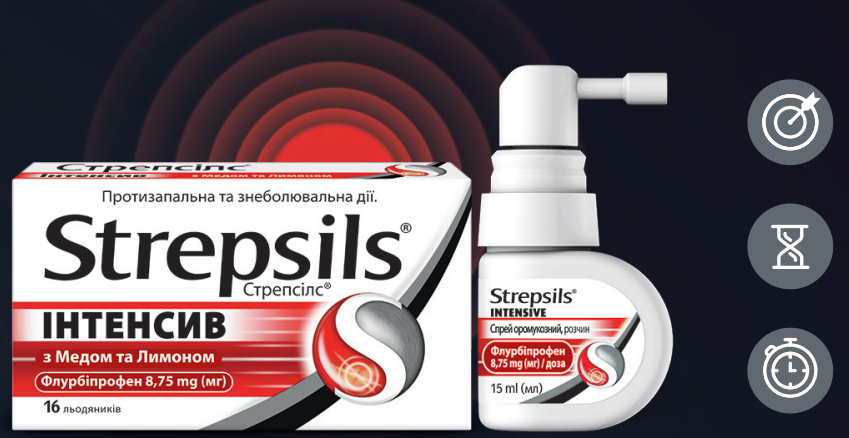

Містить флурбіпрофен (місцевий НПзП) - потужна протизапальна та знеболювальна дії

Діє швидко: заспокійливий та обволікаючий ефект льодяників через 2 хвилини; спрей - 3 5-ї хвилини

Надає тривале полегшення: льодяники до 4 годин; спрей - до 6 годин

\section{Strepsils} J.G. et al. Antibiotic use in acute respiratory infections and the ways patients pressure physicians for a prescription. The Journal of family practice vol. 50,10 (2001): 853-8. 3. Goossens $\mathrm{H}$. et al. Outpatient antibiotic use in Europe and association with resistance: a cross-national database. https://pubmed.ncbi.nlm.nih.gov/15708101/. 4. World Health Organization. The evolving threat of antimicrobial resistance. Options for action. 2012. http://apps. Who.int/iris/bitstream/handle/10665/44812/9789241503181_eng.pdf? sequence=1. 5. Shephard A. et al. Randomised, double-blind, placebo-controlled studies on flurbiprofen $8.75 \mathrm{mg}$ lozenges in patients with/without group
$\mathrm{A}$ or C streptococcal throat infection, with an assessment of clinicians' prediction of 'strep throat. International journal of clinical practice vol. 69,1 (2015): $59-71$. 6. Shephard A. et al. Flurbiprofen $8.75 \mathrm{mg}$ spray or lozenge provides relief A or C streptococcal throat infection, with an assessment of clinicians' prediction of 'strep throat. International journal of clinical practice vol. 69,1 (2015): 59-71. 6. Shephard A. et al. Flurbiprofen 8.75 mg spray or lozenge provides relie

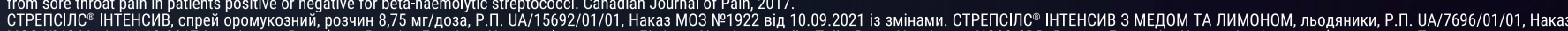
М03 №1246 від 11.10.2017 із змінами. Виробник: Реккітт Бенкізер Хелскер Інтернешнл Лімітед, Ноттінгем сайт, Тейн Роуд, Ноттінгем, NG90 2DB, Велика Британія. Категорія відпуску: без рецепта. Перед застосуванням адресою: contact_uа@rb.com. Дзвінки зі стаціонарних телефонів по Україні безкоштовні. Вартість дзвінків із мобільних телефонів визначається згідно з тарифами мобільного оператора. Представник заявника в Україн: TOB «PКККІТТ БЕНКІӞЕР УКРАЇА», Україна 04073 Київ, пр. Степана Бандери, 28А, літера Г, оф. 80, тел.: +38 (044) 390-50-41. 